\title{
Effects of Smoke and Heat-Shock on Germination in Eight Perennial Reseda Species (Resedaceae)
}

\section{Sekiz çok Yıllık Reseda (Resedaceae) Türünün Çimlenmesi Üzerine Duman ve Sıcaklık Şokunun Etkisi}

\author{
Emre Çilden $^{1 \oplus}$, Gökhan Ergan ${ }^{2,3}{ }^{\oplus}$, Cansu Ülgen ${ }^{\bullet}$, Şinasi Yıldırımlı ${ }^{1 \oplus}$ and Çağatay Tavşanoğlu2 \\ ${ }^{1}$ Division of Botany, Department of Biology, Hacettepe University, Beytepe, Ankara, Turkey. \\ ${ }^{2}$ Division of Ecology, Department of Biology, Hacettepe University, Beytepe, Ankara, Turkey. \\ ${ }^{3}$ Eastern Mediterranean Research Association, 182, Yağca St., Döşemealt, Antalya, Turkey.
}

\section{ABSTRACT}

\begin{abstract}
Reseda is an understudied genus regarding germination ecology. We studied the germination response of eight perennial

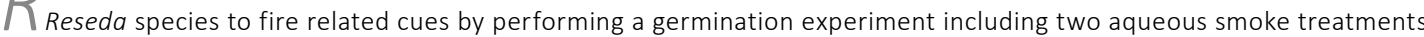
(at $1: 5$ and $1: 20$ concentrations), one heat shock $\left(100^{\circ} \mathrm{C}\right.$ for $5 \mathrm{~min}$.) treatment, and two corresponding controls. Smoke slightly decreased germination percentage in $R$. aucheri ssp. rotundifolia and $R$. minoica, and the reduction in $R$. luteola was statistically significant $(\mathrm{P}<0.01)$. In contrary, smoke promoted germination in $R$. coodei, $R$. globulosa, and $R$. orientalis slightly, and markedly in $R$. anatolica (from 3 to $11 \%$; $P=0.055$ ). Heat shock treatment did not affect the germination in three of four species tested, but significantly increased germination percentage in $R$. luteola in comparison to the control $(P=0.046)$. Consequently, there was no consistent germination response to smoke or heat shock in Reseda species studied. This study is the most comprehensive study tested fire-related germination of several Reseda species and provides the first germination results on seven Reseda species. Further studies that include more species and treatments would show a more completed figure for fire-related germination patterns in the genus Reseda.
\end{abstract}

\section{Key Words}

Germination, heat shock, Reseda, smoke.

\section{öz}

\begin{abstract}
Reseda çimlenme ekolojisi bakımından az çalışılmış bir cinstir. Bu çalışmada, sekiz çok yıllık Reseda türünün yangınla ilişkili

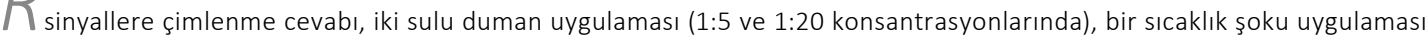
$\left(100^{\circ} \mathrm{C}^{\prime}\right.$ de 5 dakika) ve iki kontrol grubu içeren bir çimlenme deneyi gerçekleştirilerek araştırılmıştır. Duman, $R$. aucheri ssp. rotundifolia ve $R$. minoica'da yüzeysel bir şekilde, $R$. luteola'da ise istatistiksel olarak anlamlı bir şekilde $(P<0,01)$ çimlenmeyi azaltmıştır. Bunun aksine, duman $R$. coodei, $R$. globulosa ve $R$. orientalis'de yüzeysel olarak, $R$. anatolica'da ise belirgin olarak (\%3'den \%11'e; P = 0.055) çimlenmeyi artırmıştır. Sıcaklık şoku uygulaması test edilen dört türün üçünün çimlenmesini etkilemezken, $R$. luteola'nın çimlenme yüzdesini kontrole göre belirgin olarak artırmıştır ( $P=0.046)$. Sonuç olarak, çalışmada incelenen Reseda türlerinde duman ya da sıcaklık şokuna karşı tutarlı bir çimlenme cevabı gözlenmemiştir. Bu çalışma, çok sayıda Reseda türünün yangınla ilişkili çimlenmesini inceleyen en kapsamlı çalışmadır ve yedi Reseda türü için ilk kez çimlenme bulgusu sunmaktadır. İleride daha çok sayıda tür ve uygulama içerecek şekilde yapılacak çalışmalar, Reseda cinsinde yangınla ilişkili çimlenme örüntülerini daha kapsamlı bir şekilde ortaya koyacaktır.
\end{abstract}

\section{Anahtar Kelimeler}

Çimlenme, sıcaklık şoku, Reseda, duman.

Article History: Received: Aug 10, 2020; Revised: Mar 10, 2021; Accepted: Mar 10, 2021; Available Online: Jun 10, 2021 DOI: $\underline{\text { https://doi.org/10.15671/hjbc.768365 }}$

Correspondence to: Ç. Tavşanoğlu, Division of Ecology, Department of Biology, Hacettepe University, Beytepe, Ankara, Turkey.

E-Mail: ctavsan@hacettepe.edu.tr 


\section{INTRODUCTION}

T he genus Reseda L., and in a broad sense Resedaceae family, has drawn relatively less attention regarding the seed science and germination ecology [1]. Among others, R. lutea has drawn additional attention as it is an introduced and weed species in Australia [2] and North America [3]. It is known that $R$. lutea and $R$. suffruticosa has physiological dormancy and germinate well at various temperatures between 10 and $30^{\circ} \mathrm{C}[2,4,5]$. For $R$. lutea, dark conditions and being buried are better than light conditions and being on the surface for germination $[2,5]$, but there is also a result indicating no effect of light on germination in this species [6]. On the contrary, light conditions break dormancy in R. luteola [6]. It is also known that myrmecochory and unassisted dispersal are the main seed dispersal mechanisms in species of Reseda genus [1,7].

To date, the germination patterns in only two species of Reseda has been tested with regards to fire-related cues such as heat shock and smoke. Germination in $R$. lutea is not stimulated by moderate- or high-intensity heat shocks [8,9], but a slight increase in germination occurs in low-intensity heat shocks [9]. Similarly, R. luteola also found not to respond to heat shocks [8]. Smoke effect on germination has only once tested for any Reseda species, and this study shows that germination of $R$. lutea is inhibited by aqueous smoke application [9]. Nitrate, sometimes considered as another fire cue since its level increase in the soil in early post-fire environments [10], is also known to stimulate germination in $R$. lutea and R. luteola [6].

Our knowledge of the seedling establishment patterns of Reseda species in post-fire environments is also limited. There are records of successful post-fire seedling emergence in $R$. phyteuma [7,11,12] and R. luteola [13] but no seedling of $R$. lutea was found in burned sites [14]. As far as we know, there is no other record of the presence of Reseda species in burned areas.

Our study aimed to test the germination response of several Reseda species to fire related cues, heat shock and smoke. Considering a priori information about the seedling establishment of some Reseda species in post-fire environments, we expected that germination in some species we tested in the study will improve after we apply fire-related cues to seeds. For this purpose, we performed a germination experiment including one heat shock and two aqueous smoke treatments on eight Reseda species naturally grown in Turkey.

\section{MATERIALS and METHODS}

\section{Taxa}

Reseda is the largest genus of the Resedaceae family, with approximately 65 species mainly distributed in the Mediterranean basin and southwestern Asia [15]. The species of Reseda are annual or perennial herbs and occur in limestone or gypseous soils and arid or semi-arid environments [15]. The Resedaceae family is located in the order Brassicales according to APG IV system [16], and the genus Reseda consists of 4 subgenera (Neoreseda, Glaucoreseda, Luteola) and three sections (Leucoreseda, Reseda, Phyteuma) [17]. This subgeneric classification is based on morphological differences, petal structures, number of carpels, placental positioning, seed size, and testa ornamentations $[18,19]$. This classification takes its final shape according to molecular data [20].

Reseda is the only genus of the Resedaceae family in Turkey, including 18 indigenous taxa of which ten are endemic, whereas nine of them found only in Turkey [17,18,21-33]. The taxa included in the current study reflect and represent the variety of subgeneric classification of the Reseda species in Turkey.

\section{Seed collection, storage, and preparation}

Fruits of eight Reseda species were collected from different locations in Turkey between September 2013 and April 2015 (Table 1). The collections were conducted before the time of seed dispersal for each species. Fruits were collected from min. 10 individuals for each species. All these species are perennial herbs, and five are of conservation importance as they have been assigned to various threat categories by IUCN (Table 1). Fruits had been stored at room temperature and moisture in a dark place until the germination experiment was conducted in December 2015. Before the experiment, seeds were separated from fruit parts by hand and using sieves of different mesh sizes. Voucher specimens of plant taxa were deposited in a the Hacettepe University Herbarium (HUB), Ankara, Turkey.

\section{Preparation of smoke solutions}

Aqueous smoke solutions were prepared by using the procedure described in Jäger et al. [34]. Four replicates of dry plant material composed of Quercus coccifera le- 
Table 1. The list of Reseda species included in the study. The location (Loc; latitude, longitude, and altitude) and the date (Date) of seed collection, IUCN threat category (TC), phytogeographic region (Phyto; Med: Mediterranean, E.Med: Eastern Mediterranean, M.Med: Mountain Mediterranean, Ir-Tur: Irano-Turanian, Eux: Euxine hinterland, Cosm: Cosmopolitan), seed surface ornamentation (Surf; p: papillose, r: rugose, rl: rugulose, s: smooth), and seed size (SSize) are given for each taxa.

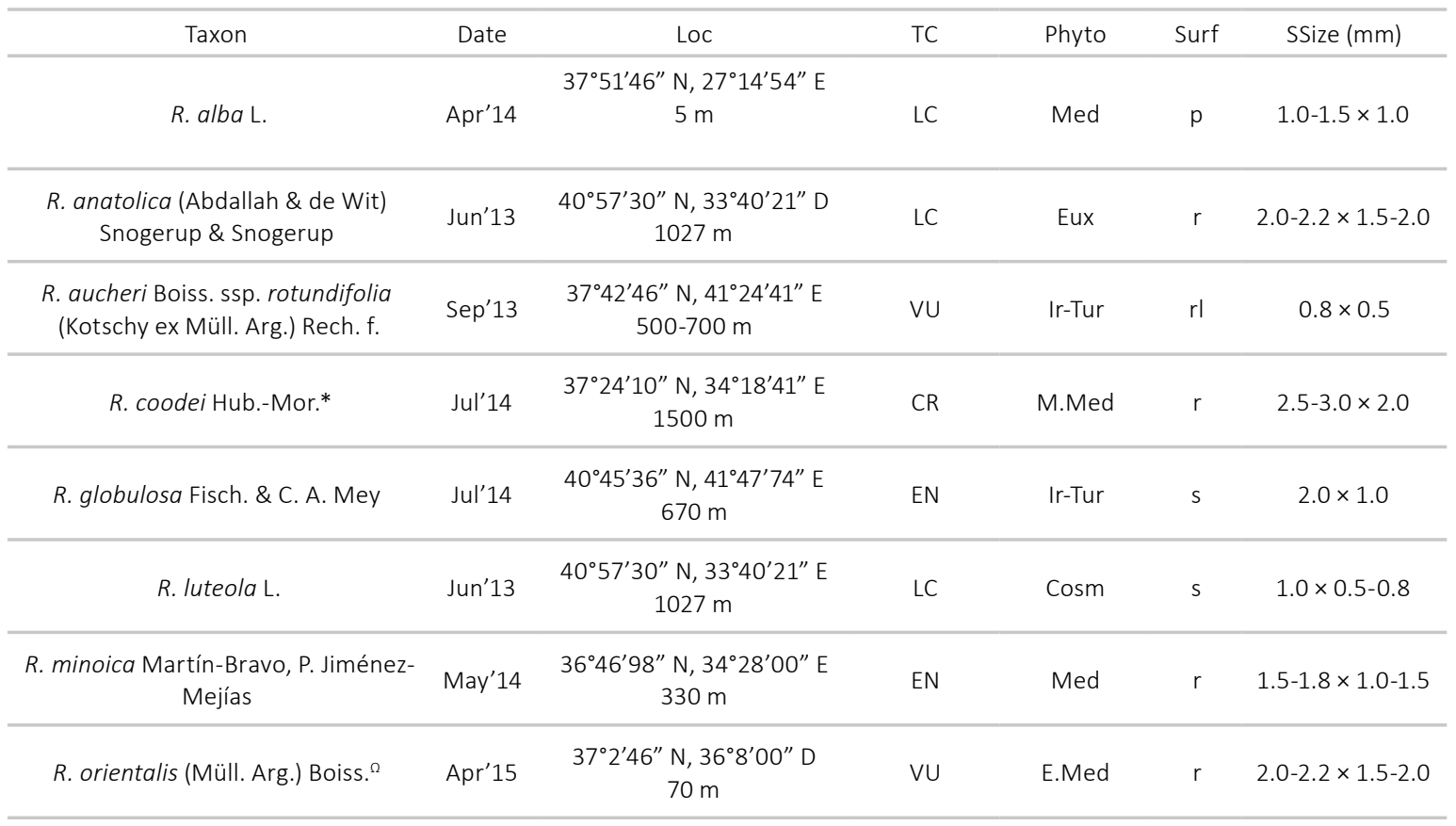

*Endemic to Turkey; $\Omega$ rare species.

aves, and small twigs (5 g for each replicate) were grounded into small pieces, placed in metallic containers, and heated in a temperature-controlled oven between $190-195^{\circ} \mathrm{C}$ for $30 \mathrm{~min}$. Before placed in the oven, metallic containers were covered with an aluminum foil. In this way, containers were able to keep the smoke generated from the burnt plant material. After the treatment, $50 \mathrm{ml}$ of distilled water was added to and mixed with the plant material in the container, and then was left for $10 \mathrm{~min}$. This solution was filtered into a bottle to obtain the stock smoke solution. Later, one $\mathrm{ml}$ stock solution was diluted in 5 and $20 \mathrm{ml}$ of distilled water to prepare lower concentrations of smoke solutions that will be used in the experiment (1:5 and 1:20 smoke solutions).

\section{The germination experiment}

For all species included in the study, a group of seeds placed into Eppendorf tubes including aqueous smoke solutions for $24 \mathrm{~h}$ (four replicate of 25 seeds for each smoke treatment). Another group of seeds were placed in the tubes including distilled water to serve as the control for smoke treatments. For heat shock treatment, we only used four species in which enough seeds were available, and a group of seeds placed into alumi- num pockets were subjected to $100^{\circ} \mathrm{C}$ for $5 \mathrm{~min}$. in a temperature-controlled oven. Heat shock treatments were separately applied to four replicates of 25 seeds for each species. Four replicates of non-treated seeds were also included in the study to serve as a control group for the heat shock treatment.

After the treatments were applied, seeds were sown into Petri dishes containing agar as a substrate. Then, the dishes were placed in a temperature- and lightcontrolled cabinet at $20^{\circ} \mathrm{C}$ under $12: 12 \mathrm{~h}$ photoperiod (dark/light) conditions (Fig. 1). These incubation conditions are within the suitable range of many Reseda species [2,4,5]. Germinations were daily checked until germinations became infrequent in any treatment, then once for two or three days. In each check, germinated seeds were counted and removed from the Petri dishes. At the end of the experiment (40 days after the incubation was initiated), a cut test was performed on the seeds remained in Petri dishes to determine their viability. Seeds with firm, white, and healthy embryos were recorded as viable, and ones including rotten embryos as non-viable. Seeds without an embryo (i.e., empty seeds) were also recorded. 

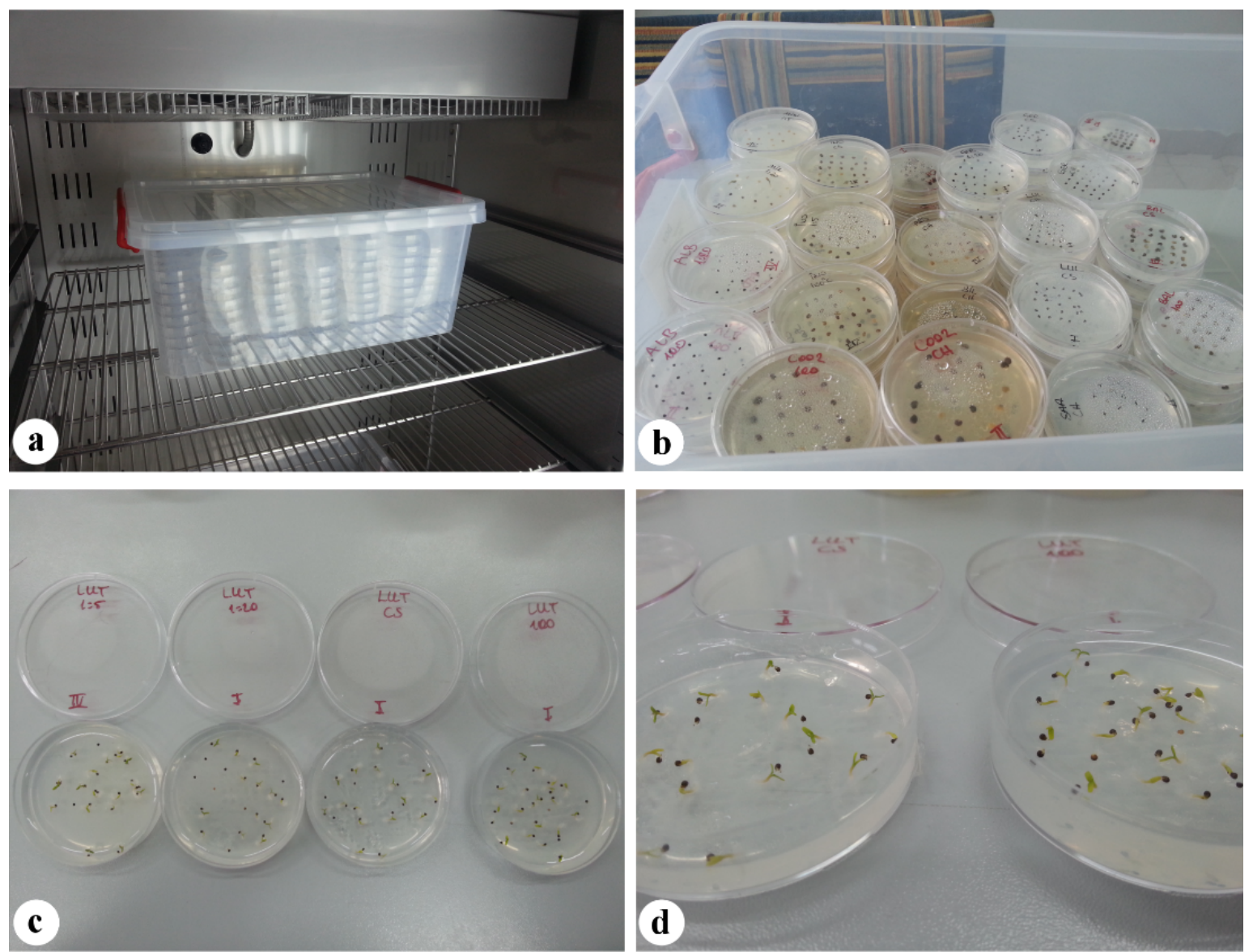

Figure 1. The germination experiment. The climate cabinet where incubation conditions were set (a), Petri dishes included the sown seeds (b, c), and the germinated $R$. luteola seeds (d) are shown.

\section{Data analysis}

For each replicate Petri dish, empty seeds were removed from the data to correct the initial seed number for each replicate. For each species, the final germination of each treatment was compared with their corresponding control (smoke control, CS or heat shock control, $\mathrm{CH}$ ) using the analysis of deviance (a generalized linear model). In this analysis, we considered the germinated versus nongerminated seeds in each replicate, and therefore assumed a binomial error distribution [35,36]. The statistical analysis was performed on R software [37].

\section{RESULTS and DISCUSSION}

Germination in Reseda species included in the study were variable in the control, as three had very low germination $(<4 \%$, i.e., high dormancy level), one had very high germination (> $85 \%$, i.e., low dormancy level), and others were found in-between these extremes (Table 2).
Germination percentage slightly improved in $R$. anatolica, $R$. coodei, $R$. globulosa, and $R$. orientalis in, at least, one of the smoke treatments. However, these improvements were not statistically significant (Table 2), but the more pronounced increase in $R$. anatolica (from 3 to $11 \%$ ) was critically significant ( $P=0.055$, Table 2 ). On the other hand, the germination in remaining Reseda species were negatively affected from the smoke treatments ( $R$. aucheri ssp. rotundifolia, $R$. luteola, and $R$. minoica), and the reduction in germination percentage was statistically significant in $R$. luteola $(P=0.007$ in $1: 5$, and $P=0.006$ in 1:20 treatment; Table 2). Heat shock treatment did not affect the germination in three of four species tested (Table 2). On the other hand, heat shock application significantly increased germination percentage in comparison to the control in R. luteola ( $\mathrm{P}$ $=0.046$; Table 2 ) . 
Table 2. Mean germination percentages $( \pm \mathrm{SE})$ in smoke $(1: 5$ and $1: 20)$ and heat shock treatments $\left(100^{\circ} \mathrm{C} 5^{\prime}\right)$ and corresponding controls $(\mathrm{CS}$ and $\mathrm{CH})$ for each Reseda species included in the study. The significance of the comparison of germination percentage in each treatment with the corresponding control is given (ns, not significant; $\neq 0.10<P<0.05$; ${ }^{*} P<0.05$; $* * P<0.01$ ). "-" means that the treatment could not be applied due to the lack of enough number of seeds.

\begin{tabular}{|c|c|c|c|c|c|}
\hline \multirow[b]{2}{*}{ Taxa } & \multicolumn{3}{|c|}{ Smoke experiment } & \multicolumn{2}{|c|}{ Heat shock experiment } \\
\hline & CS & $1: 20$ & $1: 5$ & $\mathrm{CH}$ & 100 \\
\hline R. $a l b a$ & $1.0 \pm 1.0$ & $2.0 \pm 1.1 \mathrm{~ns}$ & $1.0 \pm 1.0 \mathrm{~ns}$ & 0 & $1.0 \pm 1.0 \mathrm{~ns}$ \\
\hline R. anatolica & $3.4 \pm 2.2$ & $2.0 \pm 1.2 \mathrm{~ns}$ & $10.7 \pm 3.7 \neq$ & $1.2 \pm 1.2$ & $2.1 \pm 1.2 \mathrm{~ns}$ \\
\hline R. aucheri ssp. rotundifolia & $50.4 \pm 12.3$ & $31.0 \pm 7.4 \neq$ & $40.0 \pm 7.0 \mathrm{~ns}$ & $55.2 \pm 6.5$ & $50.0 \pm 9.6 \mathrm{~ns}$ \\
\hline R. coodei & $1.6 \pm 1.4$ & $5.3 \pm 1.2 \mathrm{~ns}$ & $5.7 \pm 1.2 \mathrm{~ns}$ & - & - \\
\hline R. globulosa & $35.4 \pm 7.5$ & $37.4 \pm 8.9 \mathrm{~ns}$ & $45.9 \pm 7.0 \mathrm{~ns}$ & - & - \\
\hline R. luteola & $91.0 \pm 3.3$ & $76.2 \pm 2.1 * *$ & $76.9 \pm 8.2 * *$ & $86.9 \pm 1.5$ & $95.6 \pm 0.2 *$ \\
\hline R. minoica & $58.0 \pm 8.7$ & $51.6 \pm 5.6 \mathrm{~ns}$ & $35.5 \pm 14.3 \mathrm{~ns}$ & - & - \\
\hline R. orientalis\& & $10.7 \pm 10.7$ & $33.0 \pm 4.5 \mathrm{~ns}$ & - & - & - \\
\hline
\end{tabular}

\& Two replicates were used.

As far as we know, we obtained the first germination results for all the species we included in the study, except Reseda luteola $[6,8]$. Moreover, our study provides the first results of the germination response of the studied species to smoke. Germination inhibition by smoke was previously found in $R$. lutea [9], and our findings on $R$. aucheri ssp. rotundifolia, $R$. luteola, and $R$. minoica support this result. On the other hand, our results also show that germination in some Reseda species can be improved by the application of aqueous smoke solutions. Our study indicates that there is interspecific variability in Reseda regarding the germination response to smoke.

Our record for $R$. luteola is the first one for heat shockimproved germination in any Reseda species so far tested $[8,9]$. However, this result contradicts with that of Luna et al. [8], in which found no germination response of $R$. luteola to various heat shock temperatures. This difference may be due to the different light conditions applied in two studies (full dark in [8], and 12:12 h pho- toperiod in the present study). Indeed, R. luteola germinate only in light conditions, but not in darkness [6]. Although we detected a substantial variability in dormancy levels among the studied species, we will not speculate about their dormancy status since we only included one temperature and light condition in our study.

In conclusion, there was no consistent germination response to smoke or heat shock in Reseda species studied, but we observed a substantial variation among species. Our study is the most comprehensive germination study tested germination properties of several Reseda species in relation to fire-related cues (i.e., heat shock and smoke) and provides the first germination results on seven Reseda species. However, more detailed studies including more species and treatments are required to fully understand the germination patterns in the genus Reseda. 


\section{Acknowledgments}

We thank B. Özüdoğru, G. Zare, A. Doğru-Koca, Ç. Özenirler, H. Altınözlü, Ö. Çam, C.B. Kapçak, Z.Z. Acar, H. Gülcan, Y. Ilkı, and Şinasi and Şeyda Çilden for their help in fieldworks between 2013 and 2015. The fieldwork of the study was financially supported by the Hacettepe University Scientific Research Unit (project no: 013D04601003). The laboratory experiment was performed at the Functional Ecology Lab., Hacettepe University. This study was part of E. Çilden's Ph.D. dissertation submitted to Hacettepe University. The authors declare that they have no conflict of interest.

\section{References}

1. C.C. Baskin, J.M. Baskin, Seeds: Ecology, Biogeography, and Evolution of Dormancy and Germination, Ed. 2. San Diego: Elsevier/Academic Press, 2014.

2. J.W. Heap, Biology and control of Reseda lutea L. 1. Seed biology and seedling growth, Aus. J. Agr. Res., 48 (1997) 511 515

3. J.D. Harris, E.S. Davis, D.M. Wichman, Yellow mignonette (Reseda lutea) in the United States, Weed Technol., 9 (1995) 196-198.

4. A. Escudero, L.F. Carnes, F. Pérez-García, Seed germination of gypsophytes and gypsovags in semi-arid central Spain, J. Arid Environ., 36 (1997) 487-497.

5. Y. Doğan, S. Başlar, H.H. Mert, A study on Reseda lutea L. distributed naturally in West Anatolia in Turkey, Acta Bot. Croat., 61 (2002) 35-43.

6. B. Luna, J.M. Moreno, Light and nitrate effects on seed germination of Mediterranean plant species of several functional groups, Plant Ecol., 203 (2009) 123-135.

7. Ç. Tavşanoğlu, J.G. Pausas, A functional trait database for Mediterranean Basin plants, Sci. Data, 5 (2018) 180135

8. B. Luna, J.M. Moreno, A. Cruz, F. Fernández-González, Heatshock and seed germination of a group of Mediterranean plant species growing in a burned area: an approach based on plant functional types, Environ. Exp. Bot. 60 (2007) 324333.

9. Ç. Tavşanoğlu, Ş.S. Çatav, B. Özüdoğru, Fire-related germination and early seedling growth in 21 herbaceous species in Central Anatolian steppe, J. Arid Environ., 122 (2015) 109-116.

10. Ç. Tavşanoğlu, G. Ergan, Ş.S. Çatav, G. Zare, K. Küçükakyüz, B. Özüdoğru, Multiple fire-related cues stimulate germination in Chaenorhinum rubrifolium (Plantaginaceae), a rare annual in the Mediterranean Basin, Seed Sci. Res. 27 (2017) 26-38.

11. R.N. Caturla, J. Raventós, R. Guàrdia, V.R. Vallejo, Early postfire regeneration dynamics of Brachypodium retusum Pers. (Beauv.) in old fields of the Valencia region (eastern Spain), Acta Oecol., 21 (2000) 1-12.

12. C. Buhk, P. Sánchez-Gómez, I. Hensen, Plant regeneration mechanisms during early post-fire succession in southeastern Spain, Feddes Repertorium, 116 (2005) 392-404.

13. B. Céspedes, I. Torres, B. Pérez, B. Luna, J.M. Moreno, Burning season does not affect post-fire regeneration but fire alters the balance of the dominant species in a seederdominated Mediterranean shrubland, Appl. Veg. Sci., 17 (2014) $711-725$
14. D. Kazanis, M. Arianoutsou, Long-term post-fire vegetation dynamics in Pinus halepensis forests of Central Greece: A functional group approach, Plant Ecol. 171 (2004) 101-121.

15. S. Martín-Bravo, H. Meimberg, M. Luceño, W. Märkl, V. Valcárcel, C. Bräuchler, P. Vargas, G. Heubl, Molecular systematics and biogeography of Resedaceae based on ITS and trnL-F sequences, Mol. Phyl. Evol., 44 (2007) 1105-1120.

16. M.W. Chase, M.J.M. Christenhusz, M.F. Fay, J.W. Byng, W.S. Judd, D.E. Soltis, D.J. Mabberley, A.N. Sennikov, P.S. Soltis, P.F. Stevens, An update of the Angiosperm Phylogeny Group classification for the orders and families of flowering plants: APG IV, Bot. J. Linn. Soc., 181 (2016) 1-20.

17. M.S. Abdallah, H.C.D. De Wit, The Resedaceae: A taxonomical revision of the family (final installment), Mededeelingen van de Landbouwhoogeschool te Wageningen, 78 (1978) 1-318.

18. J. Müller Argoviensis, Monographie de la famille des Résédacées, Zürcher and Furrer, 239 pp., Zürich, 1857.

19. M.S. Abdallah, The Resedaceae, A taxonomical revision of the family. Wageningen, Mededelingen Landbouwhogeschool Wageningen, c. 67-68, 1967.

20. S. Martín-Bravo, Sistematica, Evolucion y Biogeografia de la Familia Resedaceae, PhD thesis, Universidad Pablo De Olavide de Sevilla, Sevilla, 2009.

21. J. Müller Argoviensis, Resedaceae. In: Candolle, A.P. (ed.) Prodromus Systematis Naturalis Regni Vegetabilis vol. 16(2). pp. 548-589. Victor Masson, Paris, 1868.

22. M.J.E. Coode, Reseda L. In: Davis, P.H. (ed.), Flora of Turkey and the East Aegean Islands, vol 1, 498-506, Edinburg University Press, Edinburg, 1965.

23. P.H. Davis, Flora of Turkey and the East Aegean Islands, vol 10. p. 60-61, Edinburgh University Press, Edinburgh, 1988

24. N. Özhatay, Reseda L. In: Güner, A., Özhatay, N., Ekim, T., Başer, K.H.C. (eds.) Flora of Turkey and the East Aegean Islands, vol. 11. Edinburgh University Press, pp. 41-42, Edinburgh, 2000.

25. F.A. Karavelioğulları, M. Vural, H. Polat, Two new taxa from Central Anatolia, Turkey, Israel J. Plant Sci. 54 (2006) 105111.

26. N. Özhatay, Check-list of additional taxa to the supplement flora of Turkey IV, Turk. J. Bot. 33 (2009) 1-203.

27. Z. Aytaç, H. Duman, Reseda globulosa Fisch. \& C.A.Mey. (Resedaceae): a new record for the flora of Turkey, Turk. J. Bot. 34 (2010) 137-139.

28. S. Yıldırımlı, The chorology of the Turkish species of Resedaceae and Rhamnaceae families, Ot Sistematik Botanik Dergisi, 17 (2010) 187-188.

29. S.S. Kanoğlu, Reseda L. In: Güner A., Aslan, S., Ekim, T., Vural, M., Babaç, M.T. (eds.) The list of plants of Turkey (Vascular plants). pp. 786-788, N. Gökyiğit Botanik Bahçesi \& Flora Araştırmaları Derneği Yayını, i̇stanbul. [in Turkish], 2012.

30. S. Martín-Bravo, P. Jiménez-Mejías, Reseda minoica (Resedaceae), a new species from the eastern Mediterranean region, Ann. Bot. Fenn., 50 (2013) 55-60.

31. H. Yıldırım, S.G. Şenol, Reseda malatyana (Resedaceae), a new chasmophytic species from eastern Anatolia, Turkey, Turk. J. Bot. 38 (2014) 1013-1021.

32. E. Çilden, The taxonomical revision of the genus Reseda L. (Resedaceae) in Turkey, PhD thesis, 259 pp., Hacettepe University, 2016.

33. E. Çilden, Ş. Yıldırımlı, G. Zare, S. Martín-Bravo, Rediscovery of the restricted endemic Reseda balansae (Resedaceae) in Turkey, Phytotaxa, 362 (2018) 87-96. 
34. A.K. Jäger, M.E. Light, J. Van Staden, Effects of source of plant material and temperature on the production of smoke extracts that promote germination of light-sensitive lettuce seeds, Environ. Exp. Bot., 36 (1996) 421-429.

35. B. Moreira, J. Tormo, E. Estrelles, J.G. Pausas, Disentangling the role of heat and smoke as germination cues in Mediterranean Basin flora, Ann. Bot., 105 (2010) 627-635.
36. Ş.S. Çatav, K. Küçükakyüz, Ç. Tavşanoğlu, J.G. Pausas, Effect of fire-derived chemicals on germination and seedling growth in Mediterranean plant species, Basic Appl. Ecol., 30 (2018) 65-75.

37. R Core Team, R: A Language and Environment for Statistical Computing. R Foundation for Statistical Computing, Vienna, https://www.R-project.org/, 2019. 